\title{
Developmental Regulation of the Sarcoplasmic Reticulum Calcium Pump in the Rabbit Heart
}

\author{
DAVID J. FISHER, CHARLOTTE A. TATE, AND SHARON PHILLIPS \\ Department of Pediatrics, Section of Pediatric Cardiology, Baylor College of Medicine, Houston, Texas 77030 , \\ and the Department of Pharmacology, University of Houston, Texas 77204
}

\begin{abstract}
Previous studies have demonstrated that myocardial function changes during mammalian perinatal development. The purpose of this study was to evaluate the subcellular basis underlying the slower relaxation in the developing heart by examining perinatal changes in sarcoplasmic reticulum (SR) function, and in $\mathrm{SR} \mathrm{Ca}^{2+}$ pump protein and mRNA abundance. We measured $\mathrm{Ca}^{2+}$ uptake and ATPase rates in isolated fetal, newborn, and adult rabbit cardiac SR membranes. In fetal and adult SR membranes, we estimated the active $\mathrm{Ca}^{2+}$ pump protein content by measuring the steady state $\mathrm{Ca}^{2+}$-dependent phosphoenzyme content; the total $\mathrm{Ca}^{2+}$ pump protein content was estimated by Western analysis of the immunoreactive $\mathrm{Ca}^{2+}$ pumps. We isolated $\mathrm{RNA}$ from fetal and adult hearts and estimated the $\mathrm{SR} \mathrm{Ca}^{2+}$ pump mRNA content by Northern analysis. $\mathrm{Ca}^{2+}$ uptake and ATPase rates were significantly lower in the fetal and newborn SR membranes compared with the adult. The contents of active and total $\mathrm{Ca}^{2+}$ pump protein and of $\mathrm{Ca}^{2+}$ pump mRNA were $52-63 \%$ lower in the fetus than in the adult. These results indicate that a great deal of the slower sarcoplasmic reticulum $\mathrm{Ca}^{2+}$ uptake and $A$ TPase rates in the fetal rabbit heart can be related to lower $\mathrm{Ca}^{2+}$ pump mRNA and protein contents. It is evident that transcriptional and/or posttranscriptional regulation of the $\mathrm{SR} \mathrm{Ca}^{2+}$ pump may form an important part of the subcellular basis of the perinatal change in mammalian cardiac relaxation. (Pediatr Res 31: 474-479, 1992)
\end{abstract}

\section{Abbreviations}

SR, sarcoplasmic reticulum

$\mathrm{Ca}^{2+}$, calcium

cRNA, complementary RNA

The maximum rate of cardiac relaxation is slower in the developing mammalian heart than in adults of the same species (1). The rate of cardiac relaxation is a function of the rate of removal of $\mathrm{Ca}^{2+}$ from the myofibrils, which in the adult is regulated primarily by the ATP-dependent transport of $\mathrm{Ca}^{2+}$ from the cytosol into the SR lumen by the SR $\mathrm{Ca}^{2+}$ pump (2-4). The slower cardiac relaxation in the developing heart has been associated with slower $\mathrm{Ca}^{2+}$ uptake and ATPase rates in isolated cardiac SR vesicles from fetal rabbits and sheep (5-8). The demonstration of a single gene for the cardiac SR $\mathrm{Ca}^{2+}$ pump that expresses a single protein product in the heart (9-11) raised

Received October 2, 1991; accepted January 3, 1992

Correspondence: David J. Fisher, M.D., Texas Children's Hospital, Pediatric Cardiology, 6621 Fannin St., Houston, TX 77030.

Supported by grants from the Texas Affiliate of the American Heart Association (90G-221), the National Institutes of Health (AG 06220 and HL 13870), the Abercrombie Foundation, and the Alpha Phi Fraternity. the possibility that the slower SR $\mathrm{Ca}^{2+}$ transport function in the developing heart could be the result of lower $\mathrm{Ca}^{2+}$ pump mRNA and protein contents. Komuro et al. (12) demonstrated that the SR $\mathrm{Ca}^{2+}$ pump mRNA content was lower in the fetal rat heart compared with the adult. However, there have been discrepancies in the published data for the $\mathrm{Ca}^{2+}$ pump protein content during perinatal cardiac development. Komuro et al. (12) found no significant difference between fetal and adult rat cardiac $\mathrm{Ca}^{2+}$ pump protein contents, whereas Mahoney et al. (5) and Pegg et al. (7) demonstrated a significantly lower $\mathrm{Ca}^{2+}$ pump protein content in fetal than in adult sheep. We have reevaluated this issue in rabbits with a well-characterized cardiac SR membrane preparation. The results suggest that a great deal of the slower $\mathrm{SR} \mathrm{Ca}^{2+}$ transport function in the developing rabbit heart can be related to lower cardiac $\mathrm{Ca}^{2+}$ pump mRNA and protein contents.

\section{MATERIALS AND METHODS}

All of the protocols used in this study were performed according to the guidelines in the National Institutes of Health Guide for The Care and Use of Laboratory Animals, with the highest standards of humane care. They were approved by the Committee on Animal Experimentation at Baylor College of Medicine.

Isolation and characterization of SR membranes. Cardiac SR vesicles were isolated at the same time from 29-d gestation New Zealand White rabbit fetuses (term $=31 \mathrm{~d}$ ), 1- to 2-d-old newborns, and their mothers by a modification of the method of Harigaya and Schwartz (13). The mothers were anesthetized with $75 \mathrm{mg} / \mathrm{kg}$ ketamine and xylazine, and $2.5 \mathrm{mg} / \mathrm{kg}$ of acepromazine. Fifteen to $20 \mathrm{~min}$ later, the mothers underwent cervical subluxation. The fetal and maternal hearts were removed rapidly, rinsed in an iced solution of $0.9 \%$ saline, and trimmed free of atria, right ventricular free wall, and epicardial fat. The remaining left ventricular free wall and septum was washed three times in a solution of $10 \mathrm{mM} \mathrm{NaHCO}$ and $10 \mathrm{mM}$ Tris maleate $(\mathrm{pH}$ $\left.6.8,4^{\circ} \mathrm{C}\right)$, minced, and homogenized in 10 vol of the same solution $[15 \mathrm{~s} \times 3$ at $5800 \mathrm{rpm}$ with a PT3000 Brinkman Polytron (Westbury, NY)]. The homogenate was centrifuged for $5 \mathrm{~min}$ at $650 \times \mathrm{g}$, and $15 \mathrm{~min}$ at $4000 \times \mathrm{g}$. The supernatant was centrifuged for $20 \mathrm{~min}$ at $8000 \times g$, and the resulting supernatant was centrifuged at $40000 \times g$ for $30 \mathrm{~min}$. The pellet was resuspended in $0.8 \mathrm{~mL} / \mathrm{g}$ wet heart wt of $600 \mathrm{mM} \mathrm{KCl}$ and 10 $\mathrm{mM}$ Tris maleate $\left(\mathrm{pH} 6.8,4^{\circ} \mathrm{C}\right)$ with a Teflon-glass homogenizer, and centrifuged at $40000 \times g$ for $30 \mathrm{~min}$. The final pellet was resuspended in $20 \mathrm{mM}$ Tris maleate $\left(\mathrm{pH} 6.8,4^{\circ} \mathrm{C}\right)$. Protein concentrations were determined by the method of Lowry (14) with BSA as a standard. The SR membranes were frozen rapidly and stored at $-70^{\circ} \mathrm{C}$. Preliminary experiments demonstrated that there was no independent effect of the anesthetic or freezing the SR membranes on the measurements reported in this study. Additional experiments demonstrated no differences in $\mathrm{Ca}^{2+}$ ATPase and uptake rates between SR membranes isolated from hearts from nonpregnant adult rabbits and the pregnant mothers. The methods for membrane preparation for each age group were 
optimized by examining $\mathrm{Ca}^{2+}$ ATPase and uptake rates versus the speed of the homogenization probe, and the initial dilution volume.

The yield of SR membranes was calculated by dividing the mg of SR membranes that were isolated by the wet wt of left ventricular free wall and septum used for the isolation. The fold enrichment of SR membranes that was accomplished by the isolation procedure was determined by dividing the ${ }^{45} \mathrm{Ca}^{2+}$ uptake rate (see below) in the isolated SR membranes by the rate in fresh tissue homogenates (15). We estimated the amount of contaminating sarcolemma in SR membranes by calculating the recovery of the total ouabain-sensitive $\mathrm{Na}^{+}, \mathrm{K}^{+}$ATPase activity (16) in SR membranes as a percentage of the total activity in the homogenate protein. We also compared the ouabain sensitive $\mathrm{Na}^{+}, \mathrm{K}^{+}$ATPase activities in $\mathrm{SR}$ membranes and in isolated rabbit cardiac sarcolemma membranes (17). All reported $\mathrm{Na}^{+}, \mathrm{K}^{+}$ ATPase activities represent the highest values obtained after preincubation of protein with a range of saponin concentrations (18). We estimated the amount of contaminating mitochondria in SR membranes by calculating the recovery of the total azidesensitive $\mathrm{Mg}^{2+}$ ATPase (see below) in SR membranes as a percentage of the total activity in the homogenate protein (19). All assays of SR membrane function reported in this study were performed in $10 \mathrm{mM}$ sodium azide to inhibit the contaminating mitochondrial activity (19).

Measurements of $\mathrm{Ca}^{2+}$ pump function. $\mathrm{Ca}^{2+}$-dependent ATPase activity was measured at $30^{\circ} \mathrm{C}$ with a linked enzyme system of pyruvate kinase-lactate dehydrogenase by continuously monitoring $\mathrm{NADH}$ oxidation at $340 \mathrm{~nm}$ (20). The reaction was performed in $40 \mathrm{mM}$ Tris maleate $(\mathrm{pH} \mathrm{6.8)}, 100 \mathrm{mM} \mathrm{KCl}, 10$ $\mathrm{mM} \mathrm{MgCl} 2,10 \mathrm{mM}$ sodium azide, $40 \mu \mathrm{M}{ }^{45} \mathrm{CaCl}_{2}, 2 \mathrm{mM}$ P-enolpyruvate, $400 \mu \mathrm{M}$ NADH, $8.75 \mathrm{U}$ of pyruvate kinase, $12.75 \mathrm{U}$ of lactate dehydrogenase, $1 \mathrm{mM} \mathrm{Na}{ }_{2} \mathrm{ATP}$, and $20 \mu \mathrm{g}$ of $\mathrm{SR}$ protein $/ \mathrm{mL}$, in the presence and absence of $2 \mathrm{mM}$ EGTA. The difference in the ATP-dependent activity measured in the presence and absence of EGTA was calculated as the $\mathrm{Ca}^{2+}$ ATPase activity. The ATP-dependent activity measured in EGTA is reported as the $\mathrm{Mg}^{2+}$ ATPase activity.

ATP-dependent, oxalate-supported ${ }^{45} \mathrm{Ca}^{2+}$ uptake was measured at $30^{\circ} \mathrm{C}$ with a vacuum filtration technique $(0.45-\mu \mathrm{m}$ Millipore filters, type HAWP 02500 ). The reaction was performed in the conditions used for $\mathrm{Ca}^{2+}$ ATPase activity except for the addition of $5 \mathrm{mM}$ sodium oxalate and the exclusion of NADH. Timed aliquots were rapidly filtered before and after the reactions were initiated by the addition of $1 \mathrm{mM} \mathrm{Na} \mathrm{NTP}_{2}$. Each filtered aliquot was washed immediately with $5 \mathrm{~mL}$ of $40 \mathrm{mM}$ Tris maleate, $100 \mathrm{mM} \mathrm{KCl}\left(\mathrm{pH} 6.8,4^{\circ} \mathrm{C}\right)$, and counted in a liquid scintillation counter. The specific radioactivity was calculated by subtracting the nonspecific binding to filters and protein before the addition of ATP from the total radioactivity after the reaction was initiated. Uptake rates were determined by linear regression.

Estimation of active and total $\mathrm{Ca}^{2+}$ pump protein content. The content of active $\mathrm{Ca}^{2+}$ pump protein in $\mathrm{SR}$ membranes was estimated by measuring the $\mathrm{Ca}^{2+}$-dependent steady state phosphoenzyme content of cardiac SR membranes with vacuum filtration. The reaction was performed on ice in $10 \mathrm{mM} \mathrm{1,4-}$ piperazine(ethanesulfonic acid) $(\mathrm{pH} 6.8), 100 \mathrm{mM} \mathrm{KCl}, 5 \mathrm{mM}$ $\mathrm{MgCl}_{2}, 10 \mathrm{mM}$ sodium azide, $40 \mu \mathrm{M}^{45} \mathrm{CaCl}_{2}$, and $50 \mu \mathrm{g}$ protein/ $\mathrm{mL}$ in the presence and absence of $2 \mathrm{mM}$ EGTA and $5 \mathrm{mM}$ nonradioactive ATP. The reaction was initiated with $50 \mu \mathrm{M}\left[{ }^{32} \mathrm{P}\right]$ ATP, and quenched on ice after $10 \mathrm{~s}$ with $0.4 \mathrm{M} \mathrm{HClO}_{4}, 20 \mathrm{mM}$ $\mathrm{H}_{3} \mathrm{PO}_{4}$. The quenched reaction was filtered (Whatman GF-C) and washed with $50 \mathrm{~mL}$ of ice-cold $125 \mathrm{mM} \mathrm{HClO}_{4}$ and $20 \mathrm{mM}$ $\mathrm{H}_{3} \mathrm{PO}_{4}$. The validity of the filtration technique was determined by acid $\mathrm{pH}$ PAGE of the quenched reaction products, with autoradiographic detection of the phosphoenzyme (21).

The content of total $\mathrm{Ca}^{2+}$ pump proteins in SR membranes was estimated by immunodetection after electrophoretic separation of the protein. Electrophoresis of $50 \mu \mathrm{g}$ of SR protein/ lane with SDS-PAGE was performed in $7.5 \%$ polyacrylamide slab gels prepared according to Laemmli (22). The SR protein was used for Western transfer (23) to nylon membranes. The membranes were probed with an MAb to the canine cardiac $\mathrm{Ca}^{2+}$ pump, which was a generous gift from Dr. Larry Jones. Immunoreactive $\mathrm{Ca}^{2+}$ pump protein was exposed to horseradish peroxidase-labeled goat anti-mouse IgG (Pierce Labs, Rockford, IL), which was detected with 4-chloronapthol (Kirkegaard and Perry Labs, Gaithersburg, MD). The results were quantified with laser densitometry. We also used Coomassie brilliant blue staining of $5-15 \%$ gradient SDS-PAGE slab gels to detect the SR protein profile in the different isolations.

Isolation and analysis of RNA. We isolated RNA from hearts with the quanididium/phenol/chloroform solvent extraction method (RNAZOL ${ }^{\mathrm{B}}$, Biotecx Labs, Houston, TX). RNA samples were isolated at the same time from 29-d gestation fetal and maternal hearts that had been rapidly frozen at $-80^{\circ} \mathrm{C}$.

Northern analyses were performed by separating $20 \mu \mathrm{g}$ of RNA per lane in $1 \%$ agarose formaldehyde denaturing gels, with capillary transfer of the RNA to nitrocellulose membranes (24). The membranes were baked at $80^{\circ} \mathrm{C}$ for $2 \mathrm{~h}$, prehybridized in 20 $\mathrm{mL}$ of $50 \%$ formamide, $0.8 \mathrm{M} \mathrm{NaCl}, 50 \mathrm{mM} \mathrm{Na}_{2} \mathrm{HPO}_{4}, 1 \mathrm{mM}$ EDTA, $0.5 \times$ Denhardt's solution (24), and $250 \mu \mathrm{g} / \mathrm{mL}$ herring sperm DNA at $55^{\circ} \mathrm{C}$ for $3 \mathrm{~h}$, and hybridized overnight in $10 \mathrm{~mL}$ of fresh prehybridization solution to which we added $3 \times 10^{7}$ cpm of a $\left.{ }^{32} \mathrm{P}\right] \mathrm{Ca}^{2+}$ pump cRNA probe (Riboprobe, Promega, Madison, WI). The membranes were washed in $0.1 \times$ sodium chloride, sodium citrate and $0.1 \%$ SDS at $68^{\circ} \mathrm{C}$ three times for $20 \mathrm{~min}$, and the probe-RNA hybridization signals were visualized with autoradiography. The membranes were stripped free of ${ }^{32} \mathrm{P}_{\mathrm{Ca}^{2+}}$ pump cRNA probe by placing the membrane in a boiling solution of $1 \times$ sodium chloride, sodium citrate and $0.1 \%$ SDS, and allowing the solution to cool to room temperature. Each membrane was reprobed for constitutively expressed $18 \mathrm{~S}$ ribosomal RNA with $3 \times 10^{7} \mathrm{cpm}$ of $\left[{ }^{32} \mathrm{P}\right] 18 \mathrm{~S} \mathrm{cRNA}$. The membranes were washed as described above and autoradiographed. The abundances of SR $\mathrm{Ca}^{2+}$ pump mRNA and $18 \mathrm{~S}$ ribosomal RNA were quantified by laser densitometry of the hybridization bands that were detected with autoradiography. We normalized the results in each lane by dividing the $\mathrm{Ca}^{2+}$ pump mRNA content by the $18 \mathrm{~S}$ ribosomal RNA content (11).

For this project, we received generous gifts of a 677-bp EcoRIEcoRI human kidney SR $\mathrm{Ca}^{2+}$ pump cDNA (bp +772 to +1449 of HK1, see Ref. 25) and a $1.9 \mathrm{~kb}$ SalI-EcoRI mouse $18 \mathrm{~S}$ ribosomal cDNA (26). We subcloned each of the cDNA into the Bluescript plasmid (Promega), which we used to generate the cRNA hybridization probes. The human kidney $\mathrm{SR} \mathrm{Ca}^{2+}$ pump cDNA is an isoform of the cardiac/slow twitch $\mathrm{Ca}^{2+}$ pump gene, which, through alternate transcription, codes for sarcoplasmic reticulum or endoplasmic reticulum $\mathrm{Ca}^{2+}$ pump mRNA expressed in heart, kidney, gastrointestinal smooth muscle, and brain $(10,27,28)$. The alternate splice site is beyond the $3^{\prime}$ end of the probe that we used. In preliminary experiments, we determined that both of the probes that we used cross-reacted with rabbit cardiac RNA. The specificity of the probes was determined by comparison of restriction maps with the predictions from sequence data in the Genebank computer program, (Molecular Biology Information Resource, Department of Cell Biology, Baylor College of Medicine, Houston, TX) and by comparison of the sizes of the hybridized $\mathrm{Ca}^{2+}$ pump mRNA and ribosomal 18S RNA with published data $(11,26,29)$.

Data analysis. All experiments were repeated with four to nine different isolations of SR membranes or RNA. Data are presented as mean \pm SEM, or as representative individual experiments when appropriate. When the analyses compared two data groups, we used unpaired $t$ tests to detect significant differences $(p<0.05)$. When the analyses compared more than two groups, we used analysis of variance. When the computed $F$ ratio of an analysis of variance exceeded the critical $F$ ratio (at $p=0.05$ ), 
the Student-Newman-Keuls test was used to identify the groups that were significantly different.

\section{RESULTS}

Relative purity of SR membrane preparations. The yields of rabbit cardiac SR membranes were significantly lower in the fetuses and newborns than in the adults (Table 1). In contrast, there were no significant differences among the three age groups in the fold enrichment of the SR membranes by the isolation procedure, or in the ouabain-sensitive $\mathrm{Na}^{+}, \mathrm{K}^{+}$ATPase activity in the isolated SR membranes (Table 1). The ouabain-sensitive $\mathrm{Na}^{+}, \mathrm{K}^{+}$ATPase activity in the SR membranes was typically less than $2 \%$ of the activity in isolated rabbit cardiac sarcolemma membranes (Table 1). There also were no significant differences among the three age groups in the contamination of the SR membranes with sarcolemma and mitochondria. Compared with the homogenates, the percentages of recovery of sarcolemma and mitochondrial marker activities were less than 2 and 4\%, respectively (Table 1 ). All reactions were performed in $10 \mathrm{mM}$ sodium azide to inhibit the residual mitochondrial activity (19).

In agreement with previously published data (8), the rabbit cardiac SR membranes (Table 2) had a higher $\mathrm{Mg}^{2+}$ ATPase rate than typically is observed in isolated canine cardiac SR membranes (30). We found that the $\mathrm{Mg}^{2+}$ and $\mathrm{Ca}^{2+}$ ATPase activities of the adult microsomes did not migrate together through a sucrose gradient (31). The $\mathrm{Mg}^{2+}$ ATPase activity preferentially sedimented at the interface of 24 and $30 \%$ sucrose, whereas the $\mathrm{Ca}^{2+}$ ATPase activity localized to the interface of 30 and $50 \%$ (data not shown). Similar results with chicken and rabbit skeletal muscle membranes have suggested that this physically distinct $\mathrm{Mg}^{2+}$ ATPase activity is a function of a $\mathrm{t}$-tubular protein (32-34).

SR $\mathrm{Ca}^{2+}$ pump protein function and content. The $\mathrm{Ca}^{2+}$ ATPaseand oxalate-supported $\mathrm{Ca}^{2+}$ uptake rates in isolated rabbit cardiac SR membranes were significantly lower in the fetuses and newborns than in the adults (Table 2). The $\mathrm{Ca}^{2+}$ uptake rates in the cardiac homogenates showed a similar significant trend (Table 2). There were no developmental differences in the percentage of increase in the $\mathrm{Ca}^{2+}$ ATPase rates in the presence of the $\mathrm{Ca}^{2+}$ ionophore A23187 (Table 2), or in the sensitivity of SR $\mathrm{Ca}^{2+}$ uptake and ATPase to $\mathrm{Ca}^{2+}, \mathrm{ATP}, \mathrm{pH}$, and temperature (data not shown). $\mathrm{Ca}^{2+}$ uptake and ATPase rates were maximally activated at a free $\mathrm{Ca}^{2+}$ concentration of $10 \mu \mathrm{M}$ or better in all age groups (data not shown).

The number of functional SR $\mathrm{Ca}^{2+}$ pumps in isolated SR membranes, as estimated by the steady state $\mathrm{Ca}^{2+}$-dependent phosphoenzyme content, measured with a filtration assay, was lower in the fetus compared with the adult (Table 2; fetal/adult ratio $=0.48 \pm 0.05$ ). The validity of the filtration technique was demonstrated by autoradiography after separation of the reaction products with acid pH PAGE. The major protein that is phosphorylated is the 105-kd CaATPase pump (Fig. 1). Thus, the developmental differences demonstrated in the filtration assay are related to differences in the number of active $\mathrm{Ca}^{2+}$ pumps, rather than to phosphorylation of other proteins. The $\mathrm{Ca}^{2+}$ dependence of the pump also was demonstrated by the absence of phosphorylated CaATPase when the reaction is performed in the absence of $\mathrm{Ca}^{2+}$ (Fig. 1, lanes 2 and 4).

The content of total SR $\mathrm{Ca}^{2+}$ pumps in isolated SR membranes, as estimated by immunoblotting techniques, was significantly lower in the fetus compared with the adult (Fig. 2; fetal/ adult ratio $=0.37 \pm 0.05$ for $n=4 ; p<0.01$ ). These results correlate closely with the estimates of sarcoplasmic reticulum $\mathrm{Ca}^{2+}$ pump protein detected by Coomassie blue staining, which were roughly 15 and $25 \%$ of the total protein in the fetal and adult sarcoplasmic reticulum membranes, respectively (data not shown).

$S R$ CaATPase mRNA content. We estimated the content of cardiac CaATPase mRNA using Northern analysis with a 677bp EcoRI-EcoRI cRNA probe (Riboprobe) from human CaATPase cDNA (25). The location of the CaATPase message (Fig. 3 ) is consistent with the predicted $3-\mathrm{kb}$ mRNA size and with previously published data $(10,29)$. Each membrane was reprobed for the constitutively expressed 18 S ribosomal RNA with a 1.9$\mathrm{kb}$ Sall-EcoRI mouse 18S cRNA probe, and we normalized CaATPase mRNA expression for 18S mRNA expression with laser densitometry. With this method, we found that the content of CaATPase mRNA was lower in the fetal heart than in the adult (Fig. 3; fetal/adult CaATPase mRNA ratio $=0.39 \pm 0.06$ for $n=8, p<0.01$ ). The fetal/adult ratios for the number of active $\mathrm{Ca}^{2+}$ pumps, the content of total $\mathrm{Ca}^{2+}$ pump protein, and the $\mathrm{Ca}^{2+}$ pump mRNA content were not significantly different (Fig. 4).

\section{DISCUSSION}

Several previous studies have demonstrated that $\mathrm{Ca}^{2+}$ uptake and ATPase rates are slower in fetal and newborn rabbits and sheep compared with adults of the same species $(5,7-8)$. Our study confirms the slower $\mathrm{Ca}^{2+}$ transport function in the developing rabbit heart. The parallel results for $\mathrm{Ca}^{2+}$ uptake rates in the cardiac homogenates (Table 2) indicate that the results in the isolated SR membranes are representative of the in vivo physiology, and are not an artifact of the isolation procedure.

$\mathrm{Ca}^{2+}$ uptake and ATPase rates in isolated SR membranes are the result of several factors, including membrane leakiness, contamination by other organelles, the sensitivity of the $\mathrm{Ca}^{2+}$ pump to $\mathrm{Ca}^{2+}$, ATP, pH, and temperature, the effect of several additional SR proteins such as phospholamban, and the content of active $\mathrm{Ca}^{2+}$ pumps. There were no significant differences in the percentage of increase in the $\mathrm{Ca}^{2+}$ ATPase rates in the presence

Table 1. Relative purity of SR membrane preparations*

\begin{tabular}{lccc}
\hline & Fetus & Newborn & Adult \\
\hline Yield (mg/g) & $0.24 \pm 0.05 \dagger$ & $0.32 \pm 0.04 \dagger$ & $0.48 \pm 0.06$ \\
Fold enrichment of SR membranes & $21 \pm 2$ & $20 \pm 3$ & $18 \pm 2$ \\
Contamination of SR membranes & & & \\
(\% recovery) & $0.8 \pm 0.1$ & $1.0 \pm 0.1$ & $0.8 \pm 0.1$ \\
$\quad \mathrm{Na}^{+}, \mathrm{K}^{+}$ATPase (sarcolemma) & $2.9 \pm 0.4$ & $3.4 \pm 0.6$ & $2.7 \pm 0.3$ \\
Azide-sensitive $\mathrm{Mg}^{2+}$ ATPase (mi- & & & \\
tochondria) & & & \\
$\mathrm{Na}^{+}, \mathrm{K}^{+}$ATPase activity & $0.02 \pm 0.01$ & $0.04 \pm 0.01$ & \\
SR membranes & $1.02 \pm 0.04 \dagger$ & $\mathrm{ND}$ & $2.31 \pm 0.01$ \\
SL membranes & & \\
\hline
\end{tabular}

* Values represent the mean \pm SEM from four to eight different preparations. SL, sarcolemma; ND, not done. The variables were measured and calculated as in Materials and Methods. We estimated the amount of contaminating sarcolemma in SR membranes by calculating the recovery of the total ouabain-sensitive $\mathrm{Na}^{+}, \mathrm{K}^{+}$ATPase activity in SR membranes as a $\%$ of the total activity in the homogenate protein. We estimated the amount of contaminating mitochondria in SR membranes by calculating the recovery of the total azide-sensitive Mg ${ }^{2+}$ ATPase in SR membranes as a $\%$ of the total activity in the homogenate protein. $\mathrm{Na}^{+}, \mathrm{K}^{+}$ATPase activity $=$ouabain-sensitive rate, in $\mu \mathrm{mol} / \mathrm{mg} / \mathrm{min}$. All Na ${ }^{+}, \mathrm{K}^{+} \mathrm{ATPase}$ activities represent the highest values obtained after preincubation of protein with a range of saponin concentrations.

$\uparrow$ Significantly different from adults at $p<0.01$. 
Table 2. Developmental changes in $S R$ calcium transport function*

\begin{tabular}{lccc}
\hline & Fetus & Newborn & Adult \\
\hline ATPase rate & & & \\
$\mathrm{Mg}^{2+}$ & $97 \pm 9 \dagger$ & $128 \pm 12 \dagger$ & $181 \pm 16$ \\
$\mathrm{Ca}^{2+}$ & $147 \pm 13 \dagger$ & $191 \pm 18 \dagger$ & $275 \pm 22$ \\
$\mathrm{Ca}^{2+}, 2 \mu \mathrm{M} \mathrm{A23187}$ & $332 \pm 28 \dagger$ & $434 \pm 37 \dagger$ & $559 \pm 52$ \\
$\%$ increase, A23187 & $122 \pm 11$ & $125 \pm 17$ & $114 \pm 18$ \\
$\mathrm{Ca}^{2+}$ uptake rate & & & \\
SR membranes & $45 \pm 8 \dagger \ddagger$ & $143 \pm 13 \dagger$ & $270 \pm 24$ \\
Cardiac homogenates & $2 \pm 0.4 \dagger \ddagger$ & $7 \pm 1 \dagger$ & $15 \pm 2$ \\
Phosphoenzyme content & $0.40 \pm 0.05 \dagger$ & $\mathrm{ND}$ & $0.81 \pm 0.07$ \\
\hline
\end{tabular}

*Values represent the mean \pm SEM from five to nine different preparations. ND, not done. The variables were measured as in Materials and Methods. The rates and phosphoenzyme content were measured in $\mathrm{nmol} / \mathrm{mg} / \mathrm{min}$ and $\mathrm{nmol} / \mathrm{mg}$, respectively.

$\dagger$ Significantly different from adults at $p<0.01$.

$\ddagger$ Fetuses significantly different from newborns at $p<0.01$

\section{FETAL SR ADULT SR}

\section{Ca: $(+)(-)(+) \quad(-)$}

\section{CaATPase - \\ 92 -}

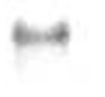

$55-$

Fig. 1. The relative contents of active fetal and adult sarcoplasmic reticulum $\mathrm{Ca}^{2+}$ pumps. Isolated $\mathrm{SR}$ membranes were phosphorylated and the reaction was quenched as described in Materials and Methods. The reaction products were separated by acid $\mathrm{pH}$ PAGE, with autoradiographic detection of the steady state phosphoenzyme. CaATPase, $\mathrm{Ca}^{2+}$ pump of the SR. The numbers at the edge of the figure represent molecular weight markers, in $\mathrm{kd}$.

of the $\mathrm{Ca}^{2+}$ ionophore A23187 (Table 2), which suggests that the developmental differences in SR membrane $\mathrm{Ca}^{2+}$ transport function did not result from artifactual differences in membrane leakiness. Our results also indicate that the SR membranes were not contaminated differentially with membranes from sarcolemma or mitochondria (Table 1). In agreement with previous studies in sheep, we found that the developmental differences in SR $\mathrm{Ca}^{2+}$ uptake and ATPase in rabbits were not the result of differences in the sensitivity to $\mathrm{Ca}^{2+}, \mathrm{ATP}, \mathrm{pH}$, or temperature $(5,7)$. We did not attempt to estimate phospholamban content in rabbits. However, the lower phospholamban content that has been demonstrated in fetal sheep (5) could not account for the slower $\mathrm{Ca}^{2+}$ transport function because phospholamban acts as a suppressor of $\mathrm{SR} \mathrm{Ca}^{2+}$ pump activity $(4,35,36)$. Thus, the slower $\mathrm{Ca}^{2+}$ transport function in the fetal heart must be from other factors.

We found that a great deal of the slower cardiac SR $\mathrm{Ca}^{2+}$ transport function in the fetus can be attributed to the lower

\section{F A}

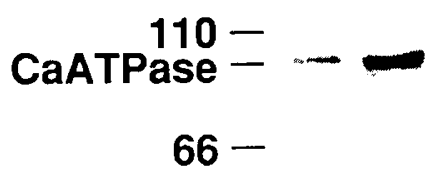

Fig. 2. The relative contents of total immunoreactive fetal and adult $\mathrm{SR} \mathrm{Ca}^{2+}$ pumps. The content of total $\mathrm{Ca}^{2+}$ pump protein in SR membranes was estimated by immunodetection after electrophoretic separation of the protein and transfer to a nylon membrane, as described in Materials and Methods. The membrane was probed with an MAb to the canine SR cardiac $\mathrm{Ca}^{2+}$ pump. Immunoreactive $\mathrm{Ca}^{2+}$ pump protein was exposed to horseradish peroxidase-labeled goat anti-mouse IgG, which was detected with 4-chloronapthol. CaATPase, $\mathrm{Ca}^{2+}$ pump of the SR. The numbers at the edge of the figure represent molecular weight markers, in kd. $F$ and $A$ indicate lanes of fetal and adult SR protein, respectively.

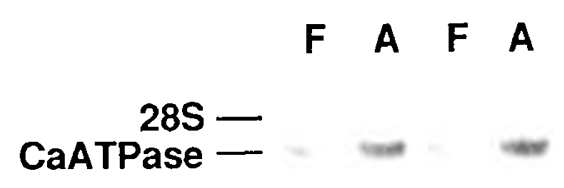

$185-$

Fig. 3. The relative contents of fetal and adult sarcoplasmic reticulum $\mathrm{Ca}^{2+}$ pump mRNA. Northern analysis was performed as described in Materials and Methods with a $\left[{ }^{32} \mathrm{P}\right] \mathrm{Ca}^{2+}$ pump cRNA probe, using a $677-$ bp EcoRI-EcoRI human kidney SR $\mathrm{Ca}^{2+}$ pump cDNA. The human kidney SR $\mathrm{Ca}^{2+}$ pump cDNA is an isoform of the cardiac/slow twitch $\mathrm{Ca}^{2+}$ pump gene, which is alternately transcribed beyond the $3^{\prime}$ end of the probe. CaATPase, $\mathrm{Ca}^{2+}$ pump of the sarcoplasmic reticulum. The numbers at the edge of the figure represent the positions of $28 \mathrm{~S}$ and $18 \mathrm{~S}$ RNA, as determined with ethidium bromide staining. $F$ and $A$ indicate lanes of fetal and adult RNA, respectively.

$\mathrm{Ca}^{2+}$ pump protein content (Table 2 and Figs. 1 and 2). This was similarly evident from our independent assays of active $\mathrm{Ca}^{2+}$ pumps and total immunoreactive pumps. These results appear to exclude the alternate possibility that the fetus could have a similar content of total pump proteins, many of which are inactive. Our results are generally supported by similar results for active and immunoreactive $\mathrm{Ca}^{2+}$ pumps in the developing sheep heart $(5,7)$, as well as the previous morphometric demonstrations of lower SR membrane contents in the developing rabbit heart $(6,37)$.

We also found that the cardiac SR $\mathrm{Ca}^{2+}$ pump mRNA content was lower in the fetal rabbit heart compared with the adult (Fig. 4). The lower $\mathrm{Ca}^{2+}$ pump mRNA content in the fetus and the 


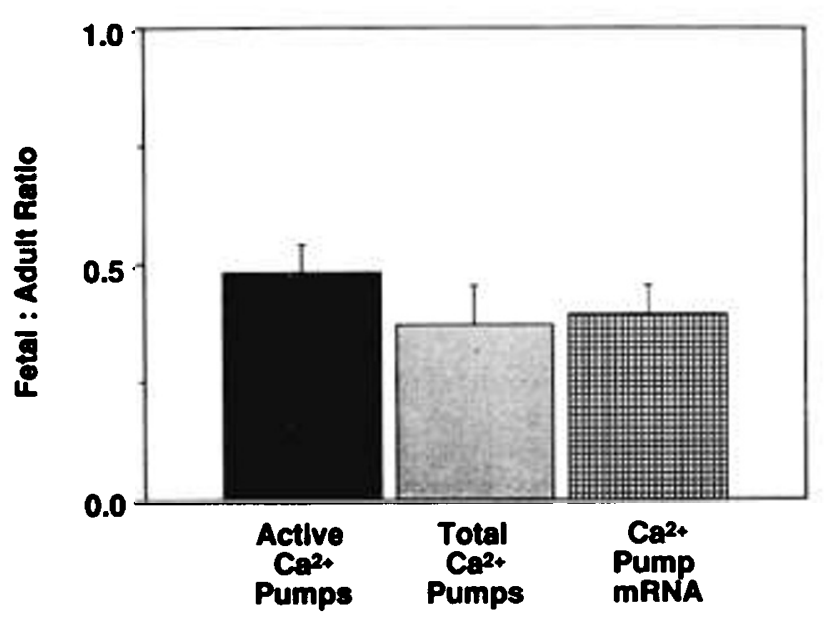

Fig. 4. The fetal/adult ratios of active $\mathrm{Ca}^{2+}$ pumps, total $\mathrm{Ca}^{2+}$ pumps, and $\mathrm{Ca}^{2+}$ pump mRNA contents. The measurements of the contents of active $\mathrm{Ca}^{2+}$ pumps, total $\mathrm{Ca}^{2+}$ pumps, and $\mathrm{Ca}^{2+}$ pump mRNA were performed as described in Materials and Methods. There were no significant differences among the three ratios.

similar fetal/adult ratios of $\mathrm{Ca}^{2+}$ pump protein and mRNA content suggest that a considerable part of the slower $\mathrm{Ca}^{2+}$ transport function in the fetal SR membranes can be related to transcriptional or posttranscriptional developmental regulation rather than to posttranslational regulation. Our $\mathrm{Ca}^{2+}$ pump mRNA data are in agreement with the data of Komuro et al. (12) in the developing rat heart. However, Komuro et al. (12) found no significant differences in $\mathrm{Ca}^{2+}$ pump protein content estimated with Coomassie blue staining of SDS-PAGE gels or in $\mathrm{Ca}^{2+}$ uptake rates in isolated SR membranes. This apparent discrepancy may result from differences between species, or from other factors such as the difficulty in isolating SR membranes from rat hearts (38).

Our results indicate that a great deal of the slower sarcoplasmic reticulum $\mathrm{Ca}^{2+}$ uptake and ATPase rates in the fetal rabbit heart can be related to lower $\mathrm{Ca}^{2+}$ pump mRNA and protein contents. It is evident that transcriptional and/or posttranscriptional regulation of the $\mathrm{SR} \mathrm{Ca}^{2+}$ pump gene may form an important part of the subcellular basis of the perinatal change in mammalian cardiac relaxation. However, these data do not exclude additional regulatory mechanisms. The recent demonstration of increased $\mathrm{Na}^{+}-\mathrm{Ca}^{2+}$ exchanger activity and immunoreactive protein content in the fetal rabbit heart compared with the adult (39) raises the possibility that the slower cardiac relaxation in the fetus may relate to a dependency on alternate mechanisms of $\mathrm{Ca}^{2+}$ egress from the cytosol (2). This is in apparent contrast with other muscle-specific proteins, such as myosin, troponin $\mathrm{T}$, and troponin I, which are additionally regulated by isoform switching within a gene family (40-42).

\section{REFERENCES}

1. Kaufman TM, Horton JW, White J, Mahony L 1990 Age-related changes in myocardial relaxation and sarcoplasmic reticulum function. Am J Physiol 259:H309-H316

2. Philipson KD, Ward $\mathrm{R} 1986 \mathrm{Ca}^{2+}$ transport capacity of sarcolemmal $\mathrm{Na}^{+}-\mathrm{Ca}^{2+}$ exchange. Extrapolation of vesicle data on in vivo conditions. J Mol Cell Cardiol 18:943-951

3. Bers DM, Bridge JHB 1989 Relaxation of rabbit ventricular muscle by $\mathrm{Na}-\mathrm{Ca}$ exchange and sarcoplasmic reticulum calcium pump. Circ Res 65:334-342

4. Tada M. Inui M 1983 Regulation of calcium transport by the ATPasephospholamban. J Mol Cell Cardiol 15:565-575

5. Mahony L, Jones LR 1986 Developmental changes in cardiac sarcoplasmic reticulum in sheep. J Biol Chem 261:15257-15265

6. Nakanishi T, Okuda H, Kamata K, Abe K, Sekiguchi, Takao A 1987 Development of myocardial contractile system in the fetal rabbit. Pediatr Res 22:201-207

7. Pegg W, Michalak M 1987 Differentiation of sarcoplasmic reticulum during cardiac myogenesis. Am J Physiol 252:H22-H31

8. Nayler WG, Fassold E 1977 Calcium accumulating and ATPase activity of cardiac sarcoplasmic reticulum before and after birth. Cardiovasc Res 11:231-237

9. MacLennan DH, Brandl CJ, Korczak B, Green NM 1985 Amino-acid sequence of a $\mathrm{Ca}^{2+}+\mathrm{Mg}^{2+}$-dependent ATPase from rabbit muscle sarcoplasmic reticulum, deduced from its complementary DNA sequence. Nature 316:696-700

10. Burk SE, Lytton J, MacLennan DH, Shull GE 1989 cDNA cloning, functional expression, and mRNA tissue distribution of a third organellar $\mathrm{Ca}^{2+}$ pump. J Biol Chem 264:18561-18568

11. De la Bastie D. Levitsky D. Rappaport L. Mercadier J-J, Marotte F. Wisnewsky C. Brovkovich V. Schwartz K, Lompre A-M 1990 Function of the sarcoplasmic reticulum and expression of its $\mathrm{Ca}^{2+}$-ATPase gene in pressure overload-induced cardiac hypertrophy in the rat. Circ Res 66:554-564

12. Komuro I, Kurabayashi M, Shibazaki Y, Takaku F, Yazaki Y 1989 Molecular cloning and characterization of a $\mathrm{Ca}^{2+}+\mathrm{Mg}^{2+}$-dependent adenosine triphosphatase from rat cardiac sarcoplasmic reticulum. J Clin Invest 83:1 1021108

13. Harigaya S, Schwartz A 1969 Rate of calcium binding and uptake in normal animal and failing human cardiac muscle. Circ Res 25:781-794

14. Lowry $\mathrm{OH}$, Rosebrough NJ 1951 Protein measurement with the Folin phenol reagent. J Biol Chem 193:265-275

15. Solaro JR, Briggs FN 1974 Estimating the functional capabilities of sarcoplasmic reticulum in cardiac muscle. Circ Res 34:531-540

16. Norby JG 1988 Coupled assay of $\mathrm{Na}^{+}, \mathrm{K}^{+}$-ATPase activity. Methods Enzymol 156:116-119

17. Meno H, Jarmakani JM, Philipson KD 1988 Sarcolemmal calcium kinetics in the neonatal heart. J Mol Cell Cardiol 20:585-591

18. Foussard-Guilbert F. Ermias A, Laget P, Tanguy G, Girault M, Jallet P 1982 Detergent effects of kinetic properties of $\left(\mathrm{Na}^{+}+\mathrm{K}^{+}\right)$-ATPase from kidney membranes. Biochim Biophys Acta 692:296-304

19. Brierley GP, Murer E, Bachmann E 1964 Studies on ion transport. III. The accumulation of calcium and inorganic phosphate by heart mitochondria. Arch Biochem Biophys 105:89-102

20. Van Winkle WB. Tate CA, Bick RJ, Entman ML 1981 Nucleotide triphosphate utilization by cardiac and skeletal muscle sarcoplasmic reticulum. J Biol Chem 256:2268-2274

21. Amory A, Foury F, Goffeau A 1980 The purified plasma membrane ATPase of the yeast Schizosaccharomyces pombe forms a phosphorylated intermediate. J Biol Chem 255:9353-9357

22. Laemmli UK 1970 Cleavage of structural proteins during the assembly of the head of bacteriophage T4. Nature 227:680-685

23. Towbin H, Staehelin T, Gordon J 1979 Electrophoretic transfer of proteins from polyacrylamide gels to nitrocellulose sheets: procedure and some applications. Proc Natl Acad Sci USA 76:4350-4354

24. Sambrook J, Fritsch EF, Maniatis T 1989 Molecular Cloning. A Laboratory Manual, 2nd Ed. Cold Spring Harbor laboratory Press, Cold Spring Harbor, NY

25. Lytton J, MacLennan DH 1988 Molecular cloning of cDNAs from human kidney coding for two alternatively spliced products of the cardiac $\mathrm{Ca}^{2+}$. ATPase gene. J Biol Chem 263:15024-15031

26. Arnheim N 1979 Characterization of mouse ribosomal gene fragments purified by molecular cloning. Gene 7:83-96

27. Gunteski-Hamblin A-M, Greeb J, Shull GE 1988 A novel $\mathrm{Ca}^{2+}$ pump expressed in brain, kidney and stomach is encoded by an alternative transcript of the slow-twitch muscle sarcoplasmic reticulum Ca-ATPase gene. J Biol Chem 263:15032-15040

28. Lytton J, Zarain-Herzberg A, Periasamy M. MacLennan DH 1989 Molecular cloning of the mammalian smooth muscle sarco(endo)plasmic reticulum $\mathrm{Ca}^{2+}$-ATPase. J Biol Chem 264:7059-7065

29. Rhorer D, Dillman WH 1988 Thyroid hormone markedly increases the mRNA coding for sarcoplasmic reticulum $\mathrm{Ca}^{2+}$-ATPase in the rat heart. J Biol Chem 263:6941-6944

30. Tate CA, Bick RJ, Chu A, Van Winkle WB, Entman ML 1985 Nucleotide specificity of cardiac sarcoplasmic reticulum. J Biol Chem 260:9618-9623

31. Fernandez JL, Rosemblatt M. Hidalgo C 1980 Highly purified sarcoplasmic reticulum vesicles are devoid of $\mathrm{Ca}^{2+}$-independent ('basal') ATPase activity. Biochim. Biophys Acta 599:552-568

32. Sabbadini RA, Okamoto VR 1983 The distribution of ATPase activities in purified transverse tubular membranes. Arch Biochem Biophys 223:107119

33. Rosemblatt M, Hidalgo C, Vergara C, Ikemoto N 1981 Immunological and biochemical properties of transverse tubule membranes isolated from rabbit skeletal muscle. J Biol Chem 256:8140-8148

34. Kirley $\mathrm{T} 1988$ Purification and characterization of the $\mathrm{Mg}^{2+}-\mathrm{ATPase}$ from rabbit skeletal muscle transverse tubule. J Biol Chem 263:12682-12689

35. Inui M, Chamberlain BK, Saito A, Flesicher S 1986 The nature of the modulation of $\mathrm{Ca}^{2+}$ transport as studied by reconstitution of cardiac sarcoplasmic reticulum. J Biol Chem 261:1794-1800

36. Fujii J, Maruyama K, Tada M, MacLennan DH 1990 Co-expression of slowtwitch/cardiac muscle $\mathrm{Ca}^{2+}$-ATPase (SERCA2) and phospholamban. FEBS Lett 273:231-234

37. Nassar R, Reedy MC, Anderson PAW 1987 Developmental changes in the ultrastructure and sarcomere shortening of the isolated rabbit ventricular myocyte. Circ Res 61:465-483

38. Feher JJ, Davis MD 1991 Isolation of rat cardiac sarcoplasmic reticulum with improved $\mathrm{Ca}^{2+}$ uptake and ryanodine binding. J Mol Cell Cardiol 23:249258 
39. Artman M 1991 Determination of $\mathrm{Na}^{+}-\mathrm{Ca}^{2+}$ exchanger and $\mathrm{Na}^{+}$-dependent $\mathrm{Ca}^{2+}$ uptake in cardiac sarcolemma from fetal, newborn, immature, and adult rabbits. Circ 84(suppl II):II-188(abstr)

40. Andeson PAW, Oakeley AE 1989 Immunological identification of five troponin $\mathrm{T}$ isoforms reveals an elaborate maturational troponin $\mathrm{T}$ profile in rabbit myocardium. Circ Res 65:1087-1093
41. Saggin L, Gorza LG, Ausoni S, Schiaffino S 1989 Troponin I switching in the developing heart. J Biol Chem 264:16299-16302

42. Lompre AM, Mercadier JJ, Wisnewsky C, Bouveret P, Pantaloni C, D'Albis A, Schwartz K 1981 Species and age-dependent changes in relative amounts of cardiac myosin isoenzymes in mammals. Dev Biol 84:286-290

\section{Announcement}

\section{4th International Meeting on Trace Elements in Medicine and Biology}

The 4th International Meeting on Trace Elements in Medicine and Biology, "Trace Elements and Free Radicals in Oxidative Diseases," will be held in Chamonix, France, April 5-9, 1993. The meeting is organized by the Society for Free Radical Research, the Sociéte Francophone d'Etude et de Recherche sur les Elements Trace Essentiels, and the Club d'Etude sur les Radicaux Libres. For registration information, contact: Professeur Alain Favier or Madame Arlette Alcaraz, Laboratoire de Biochimie C, Hôpital A. Michallon, B.P. 217X, 38043 Grenoble, Cédex 09, France, phone (33) 767654 07; FAX (33) 76426644. 